\title{
Faktor-faktor yang mempengaruhi kualitas kinerja pegawai kantor pertanahan di Kabupaten Rote Ndao
}

\author{
Affecting factors to land agency employee 's performance quality in \\ Rote Ndao regency
}

\author{
Geraldino A. Sayd, Frans Gana, \& Petrus Kase \\ Program Magister Administrasi Publik, Universitas Nusa Cendana, Kupang \\ E-mail: geraldsayd@ rocketmail.com
}

\begin{abstract}
The aim of this research is to analyzes determinant factors (input) and determinant factor (process) to employee working quality (output) in Land Agency in Rote Ndao regency. There are 6 variables used in this research with 6 independent variables and one dependent variable. 6 dependent variables consist of human resources, budget, facility, infrastructure, bureaucracy efficiency, and labor discipline; independent variable is working quality. Population in this research are 30 employees from Land Agency in Rote Ndao regency. Data analysis used in this research is Spearman's correlation analysis method. This research concludes that the six independet variables have significant influnce toward the dependent variable partially and simultaneously.
\end{abstract}

Keywords: quality performance, human resources, budget, facilities, infrastructure, bureaucracy efficiency, labor discipline

\begin{abstract}
Abstrak
Penelitian ini bertujuan untuk menganalisis pengaruh faktor determinan (input) dan faktor determinan (process) terhadap kualitas kinerja (output) di Kantor Pertanahan Kabupaten Rote Ndao. Variabel yang digunakan dalam penelitian ini menggunakan 6 (enam) variabel bebas dan 1 (satu) variabel terikat. Variabel bebas adalah sediaan sumber daya manusia, ketersediaan anggaran, ketersediaan sarana, ketersediaan prasarana, efisiensi birokrasi, disiplin kerja, sedangkan variabel terikat adalah kualitas kinerja. Populasi dalam penelitian ini adalah pegawai Kantor Pertanahan Kabupaten Rote Ndao yang berjumlah 30 orang. Teknik penarikan sampel adalah sampling jenuh. Analisis data yang digunakan adalah analisis korelasi Spearman's rho. Penelitian ini menyimpulkan bahwa secara parsial maupun simultan keenam variabel bebas mempunyai pengaruh yang signifikan terhadap variabel terikat.
\end{abstract}

Kata Kunci: Kualitas kinerja, sumber daya manusia, anggaran, sarana, prasarana, efisiensi birokrasi, disiplin kerja

\section{Pendahuluan}

Dalam era pembangunan dewasa ini, arti dan fungsi tanah bagi negara Indonesia tidak hanya menyangkut kepentingan ekonomi semata, tetapi juga mencakup aspek sosial dan politik serta aspek pertahanan keamanan. Menyadari akan fungsi tersebut maka pemerintah berusaha meningkatkan pengelolaan, pengaturan dan pengurusan di bidang pertanahan yang menjadi sumber kemakmuran dan kesejahteraan sesuai dengan ketentuan peraturan yang berlaku. Tanah-tanah yang ada di Indonesia ini diatur dengan Undang-Undang Pokok Agraria (UUPA), yaitu Undang-Undang Nomor 5 Tahun 1960 yang dikeluarkan pada tanggal 24 September 1960. Dalam penyelenggaraan pengelolaan pertanahan, khususnya yang berkaitan dengan pengelolaan penguasaan dan hak-hak atas tanah diperlukan lembaga yang berhak memberikan jaminan kepastian hukum terhadap hak atas tanah, sehingga akan 
lebih mudah bagi seseorang untuk mempertahankan haknya terhadap setiap gangguan pihak lain. Dalam hal ini lembaga yang dimaksud adalah Badan Pertanahan Nasional (BPN) untuk tingkat pusat dan Kantor Pertanahan untuk tingkat daerah. Kantor Pertanahan merupakan organisasi publik yang berwenang menyelenggarakan pengelolaan pertanahan dan memberikan pelayanan kepada masyarakat dalam bidang pertanahan.

Dibentuklah Kantor Pertanahan sebagai sebuah instansi vertikal Badan Pertanahan Nasional Republik Indonesia di Kabupaten Rote Ndao sebagai daerah otonom baru yang bertanggung-jawab kepada Kepala Kantor Wilayah Badan Pertanahan Provinsi Nusa Tenggara Timur. Kantor Pertanahan mempunyai tugas melaksanakan sebagian tugas pokok dan fungsi. Kantor Pertanahan sebagai organisasi publik dituntut untuk dapat memberikan pelayanan secara optimal kepada masyarakat melalui peningkatan kualitas kinerja. Hal ini diperlukan mengingat tujuan pelayanan pada dasarnya adalah memberikan kepuasan kepada masyarakat melalui kebutuhan, keinginan dan harapan masyarakat.

Pada era manajemen berbasis kinerja organisasi sektor publik perlu dibangunnya sistem manajemen organisasi sektor publik yang berbasis kinerja (performance based management) demi kepentingan masyarakat. Kemunculan manajemen berbasis kinerja merupakan bagian dari reformasi New Public Management yang dilakukan oleh negara-negara maju di Eropa dan Anglo Amerika sejak tahun 1980an. Fokus manajemen berbasis kinerja adalah pengukuran outcome (hasil), bukan lagi sekedar pengukuran masukan (input) dan keluaran (output). Manajemen publik yang berorientasi hasil disebut result oriented management. (Mahmudi 2010:1) menyebutnya dengan istilah results oriented government, yaitu pemerintahan yang membiayai outcome bukan input. Oleh karena itu, suatu proses (aktivitas) kinerja apabila telah dilaksanakan akan memberikan kualitas kinerja. Suatu proses (aktivitas) kinerja organisasi dapat dikatakan selesai apabila telah mencapai suatu target tertentu yang telah ditetapkan sebelumnya atau dapat pula dinyatakan selesai berdasarkan suatu batasan waktu tertentu, pada akhir tahun. Pengukuran kualitas kinerja dilakukan untuk memberikan penilaian terhadap hasil kerja atau prestasi kerja yang diperoleh organisasi, tim atau individu. Pengukuran kualitas kinerja akan memberikan umpan balik terhadap tujuan dan sasaran kualitas kinerja, perencanaan dan proses pelaksanaan kualitas kinerja. Atas dasar pengukuran kualitas kinerja dapat diambil langkah-langkah untuk melakukan perbaikan kinerja di waktu yang akan datang, karena pengukuran atau evaluasi kinerja merupakan pendapat yang bersifat evaluatif atas sifat, perilaku seseorang, dan prestasi kerja individu, kelompok/tim dan organisasi, sebagai dasar untuk keputusan dan rencana pengembangan personil dalam organisasi.

Pengaruh kualitas kinerja individu maupun tim terhadap kualitas kinerja organisasi dapat diuraikan sebagai berikut: 1) faktor kualitas kinerja individual dipengaruhi oleh pengetahuan, kemampuan, motivasi, dan peran; 2) faktor kualitas kinerja tim atau kelompok dipengaruhi oleh keeratan tim, kepemimpinan, kekompakan struktur tim, peran tim dan norma; 3) faktor kualitas kinerja organisasi dipengaruhi oleh lingkungan, kepemimpinan, struktur organisasi pilihan strategi, teknologi, kultur organisasi dan proses organisasi. Oleh karena itu, untuk mengukur kualitas kinerja sangat berhubungan dengan beberapa determinan penting ini, antara lain: a) masukan (input), terdiri atas ketersediaan sumber daya manusia, ketersediaan anggaran, ketersediaan sarana dan ketersediaan prasarana, b) aktivitas (process) terdiri atas birokrasi, disiplin kerja, dan c) keluaran (output) merupakan hasil langsung dari suatu proses atau target pencapaian program.

Hasil identifikasi terhadap kondisi sumber daya manusia di Kantor Pertanahan Kabupaten Rote Ndao menunjukkan masih rendahnya aspek kuantitas atau jumlah aparatur sipil negara yakni hanya berjumlah 30 orang. Dilihat dari formasi jabatan struktural, beberapa jabatan masih lowong, yaitu: Kepala Urusan Umum dan Kepegawaian, Kepala Seksi Hak Tanah dan Pendaftaran Tanah, Kepala Sub Seksi Tematik dan Potensi Tanah serta Kepala Sub Seksi Pengaturan Tanah Pemerintah. Selanjutnya dilihat dari aspek kualitas, kualifikasi pendidikan pegawai yang merupakan lulusan D1, DIV dan S1 hanya berjumlah 10 orang, sedangkan sebagian besar pegawai berlatar belakang pendidikan SLTA. Realisasi anggaran Tahun 2010-2014 belum digunakan sampai tuntas demi kepentingan masyarakat, sehingga sisa anggaran yang tidak terealisasikan dikembalikan ke kas 
negara. Selain itu, fasilitas kerja kurang memadai dan prasarana kerja juga kurang mendukung. Kondisi ini masih diperburuk dengan efisiensi birokrasi, terutama berkaitan dengan rasio tenaga kerja (pegawai) dalam menyelesaikan volume kerja setiap hari kerja. Selain itu masih terdapat pegawai tertentu yang kurang mentaati ketentuan jam kantor (jam masuk dan keluar: 08.00-16.00) serta meninggalkan tugas secara tidak sah pada saat jam kantor.

Bertolak dari latar belakang, maka masalah dalam penelitian ini adalah "faktor-faktor apa sajakah yang berpengaruh terhadap kualitas kinerja Kantor Pertanahan Kabupaten Rote Ndao?". Tujuan dari penelitian ini adalah menganalisis pengaruh faktor determinan input dan faktor determinan process terhadap kualitas kinerja Kantor Pertanahan Kabupaten Rote Ndao. Faktor determinan input terdiri dari ketersediaan sumber daya manusia, ketersediaan anggaran, ketersediaan sarana, ketersediaan prasarana sedangkan faktor determinan process terdiri dari efisiensi birokrasi, disiplin kerja pegawai yang berpengaruh terhadap kualitas kinerja Kantor Pertanahan Kabupaten Rote Ndao.

\section{Metode Penelitian}

Penelitian ini dilakukan di Kantor Pertanahan Kabupaten Rote Ndao. Jenis penelitian ini adalah penelitian survey. Populasi dalam penelitian ini adalah pegawai negeri sipil Kantor Pertanahan Kabupaten Rote Ndao berjumlah 30 orang. Teknik penarikan sampling yang digunakan adalah Sampling Jenuh, teknik ini digunakan sebab semua anggota populasi digunakan sebagai sampel. Informan dalam penelitian ini adalah kepala kantor, kepala seksi, staf dan masyarakat. Jenis data yang digunakan dalam penelitian ini adalah data primer dan data sekunder. Teknik pengumpulan data dalam penelitian ini adalah metode kuesioner, studi dokumentasi dan wawancara. Teknik analisis data yang digunakan dalam penelitian ini adalah analisis korelasi Spearman's rho. Untuk mengetahui tingkat signifikansi korelasi secara parsial dari keenam variabel bebas terhadap variabel terikat digunakan uji t, sedangkan untuk menguji tingkat signifikansi korelasi secara simultan variabel bebas dan variabel terikat digunakan uji F.

\section{Hasil Penelitian dan Pembahasan}

Untuk menganalisis faktor-faktor apa sajakah yang berpengaruh terhadap kualitas kinerja Kantor Pertanahan Kabupaten Rote Ndao, digunakan analisis teori sistem yang terdiri atas masukan (input), aktivitas (process) dan keluaran (output). Analisis ini mencoba untuk melihat faktor-faktor yang mempengaruhi kualitas kinerja dengan menggunakan variabel masukan (input) yang terdiri dari ketersediaan sumber daya manusia, ketersediaan anggaran, ketersediaan sarana, ketersediaan prasarana dan variabel aktivitas (process) terdiri dari efisiensi birokrasi, disiplin kerja yang berpengaruh terhadap kualitas kinerja (output).

Dari hasil analisis kualitas kinerja Kantor Pertanahan Kabupaten Rote Ndao terdiri atas 6 aspek, yaitu: (1) pelayanan administrasi pertanahan, (2) masukan dari masyarakat, (3) bantuan kepada masyarakat, (4) jenis-jenis bantuan pemerintah, (5) bentuk-bentuk pelayanan administrasi pertanahan, dan (6) pengeluhan dari masyarakat. Dilihat dari aspek pelayanan yang dihasilkan atau dikerjakan oleh pegawai di Kantor Pertanahan Kabupaten Rote Ndao mempunyai kualitas yang baik dilihat dari cara memberikan pelayanan yang sesuai dengan standar prosedur operasi pengaturan dan pelayanan (SPOPP), namun terkadang pelayanan mengalami hambatan karena keterbatasan sumber daya manusia, dana dan fasilitas yang belum memadai. Untuk aspek masukan ataupun keluhan dari masyarakat terkait pelayanan yang diberikan sudah cukup baik namun perlu ditingkatkan untuk mendapat umpan balik dari eksternal. Selanjutnya aspek jenis dan bantuan kepada masyarakat yang memenuhi persyaratan sebagai subyek peserta Prona dan Pronada dibagikan secara merata, namun di lapangan sering terlambat realisasinya disebabkan keterbatasan sumber daya mar nusia dan sarana yang ada serta hal-hal teknis lainnya. 
Analisis sumber daya manusia terdiri atas 8 aspek, yaitu: (1) jumlah pegawai, (2) beban kerja, (3) tingkat pendidikan, (4) keahlian atau disiplin ilmu (5) diklat, (6) ketepatan waktu pekerjaan, (7) hasil dari pekerjaan, dan (8) masa kerja. Dilihat dari jumlah pegawai masih kurang memadai dan selain itu juga terdapat kekosongan pejabat struktural yang belum diisi pada level Kepala Seksi maupun Kepala Sub Bagian sehingga terjadinya rangkap jabatan. Hal tersebut menandakan bahwa distribusi beban kerja tidak merata dan proposional di setiap seksi. Untuk tingkat pendidikan sebagian besar adalah SLTA, sedangkan keahlian atau ketrampilan teknis tidak dimiliki oleh semua pegawai dilihat berdasarkan latar belakang pendidikan dan pelatihan (diklat) yang diikuti. Untuk hasil pekerjaan dan waktu sudah sesuai standar prosedur operasi pengaturan dan pelayanan (SPOPP). Dilihat dari masa kerja rata-rata di atas 10 tahun.

Analisis anggaran terdiri atas 3 aspek, yaitu: (1) realisasi anggaran, (2) jumlah anggaran, dan (3) penyusunan anggaran. Dilihat dari jumlah anggaran tiap tahun ada peningkatan namun realisasi di lapangan masih mengalami hambatan sehingga sisa anggaran disetor kembali ke kas negara. Untuk penyusunan anggaran sering mengalami keterlambatan disebabkan akses internet yang kurang mendukung dan terbatasnya sumber daya manusia di bidang keuangan.

Analisis sarana terdiri atas 5 aspek, yaitu: (1) kebutuhan pegawai, (2) jenis-jenis peralatan kantor, (3) kualitas peralatan kantor, (4) hasil kerja peralatan kantor, dan (5) jumlah fasilitas kantor. Dilihat dari kebutuhan masih kurang memadai baik jenis peralatan dan kualitas serta jumlah nya sehingga hasil pekerjaan menjadi tidak maksimal dan menghambat kelancaran proses pelayanan administrasi pertanahan. Keterbatasan dalam fasilitas akan mempengaruhi motivasi bekerja dari pegawai, karena dengan adanya fasilitas atau peralatan kantor yang lengkap dan memadai akan mendukung kelancaran proses bekerja.

Analisis prasarana terdiri atas 4 aspek, yaitu: (1) jumlah ruangan kantor, (2) aktivitas pegawai, (3) luas ruangan kantor, dan (4) ukuran ruangan kantor. Dilihat dari pembagian ruangan atau jumlah ruangan yang ada sudah merata per bagian dan seksi. Untuk ukuran dan luas kantor tidak terlalu luas (dan terkesan padat) sehingga tingkat kebisingan yang masih tinggi.

Analisis efisiensi birokrasi dilihat dari aspek rasio pegawai dan volume kerja. Pada hakikatnya birokrasi merupakan struktur organisasi di sekitar pemerintahan yang memiliki ruang lingkup tugas sangat luas serta memerlukan organisasi besar dengan sumber daya manusia yang besar pula jumlahnya. Berdasarkan data Kantor Pertanahan Kabupaten Rote Ndao, rasio pegawai menunjukkan bahwa dalam menyelesaikan volume kerja setiap hari masih kurang mencukupi kebutuhan, dilihat dari jumlah pegawai 30 orang yang seharusnya 50 orang ke atas untuk mendekatkan pelayanan administrasi pertanahan kepada masyarakat di 10 Kecamatan yang dibagi dalam 7 kelurahan dan 89 desa di wilayah Kabupaten Rote Ndao.

Analisis Disiplin Kerja terdiri atas 7 aspek, yaitu: (1) menaati ketentuan jam kerja, (2) ketepatan waktu jam masuk dan keluar kantor, (3) menciptakan dan memelihara suasana kerja yang baik, (4) waktu menyelesaikan pekerjaan, (5) kerjasama antara pegawai, (6) beban kerja pada saat jam kerja, dan (7) tidak meninggalkan tugas secara tidak sah. Diihat dari disiplin kerja pegawai dalam menaati ketentuan jam kerja baik waktu jam masuk dan keluar kantor sudah cukup baik namun masih perlu ditingkatkan lagi. Begitu pun menyangkut kerjasama antara pegawai di mana ada sikap saling menghormati satu sama lain. Oleh sebab itu setiap organisasi berupaya menciptakan peraturan atau tata tertib yang akan menjadi rambu-rambu yang harus dipenuhi oleh seluruh pegawai dalam organisasi. Keberadaan berbagai peraturan organisasi ditujukan untuk menciptakan ketertiban dalam organisasi. Dengan terlaksananya ketertiban, maka diharapkan pegawai akan bekerja dengan baik, semangat dan moral kerja tinggi, yang pada akhirnya akan meningkatkan kinerja pegawai tersebut.

Berdasarkan hasil wawancara dengan informan menyangkut kualitas kinerja Kantor Pertanahan, maka dapat dilihat pada tabel berikut ini: 


\section{Tabel 1.}

Hasil wawancara

\begin{tabular}{|c|c|c|}
\hline Variabel & Informan & Wawancara \\
\hline $\begin{array}{l}\text { 1. Kualitas } \\
\text { Kinerja } \\
\text { (output) } \\
\text { Kantor } \\
\text { Pertanahan } \\
\text { Kabupaten } \\
\text { Rote Ndao }\end{array}$ & $\begin{array}{c}\text { Kepala Sub Bagian Tata } \\
\text { Usaha }\end{array}$ & $\begin{array}{l}\text { "Kalau untuk pelayanan administrasi di Kantor Pertanahan } \\
\text { sudah mengikuti standar SPOPP, namun terkadang } \\
\text { mengalami hambatan karena adanya keterbatasan SDM, } \\
\text { anggaran dan fasilitas" (wawancara tanggal } 12 \text { November } \\
2013 \text { ) } \\
\text { "Untuk bantuan pemerintah sudah direalisasikan secara } \\
\text { merata sesuai target yang ditetapkan" (wawancara tanggal } 12 \\
\text { November 2013) } \\
\text { "Rata-rata masyarakat akan menyampaikan masukan kepada } \\
\text { pegawai jika mengalami pelayanan yang kurang } \\
\text { memuaskan" (wawancara tanggal 12 November 2013) } \\
\text { "Memang saya baru sekali ini berurusan ke kantor } \\
\text { Pertanahan,.Sementara kalau kita mengeluh ke } \\
\text { aparat disini supaya minta dipercepat, saya takut konsekuensi } \\
\text { uang lagi" (wawancara tanggal } 13 \text { November 2014) }\end{array}$ \\
\hline $\begin{array}{l}\text { 2. Sediaan } \\
\text { Sumber } \\
\text { Daya } \\
\text { Manusia }\end{array}$ & $\begin{array}{c}\text { Kepala Sub Seksi } \\
\text { Penetapan Hak Tanah } \\
\text { Kepala Sub Bagian Tata } \\
\text { Usaha }\end{array}$ & $\begin{array}{l}\text { "Masih kurangnya pegawai (staf) sebanyak 2-3 orang tiap } \\
\text { bagian serta jabatan yang lowong" (wawancara } 12 \text { November } \\
2013 \text { ) } \\
\text { "Walau ada keterbatasan dalam sumber daya namun dapat di } \\
\text { atas dengan kerjasama yang baik diantara pegawai" } \\
\text { (wawancara } 12 \text { November } 2013 \text { ) } \\
\text { "Kalau pekerjaan banyak, maka kita dibagian HTPT akan } \\
\text { kewalahan karena kekurangan pegawai" } \\
\text { (wawancara } 13 \text { November 2013) } \\
\text { "Rata-rata tingkat pendidikan di Kantor ini masih } \\
\text { berpendidikan SLTA sedangkan sebagian pegawai hanya } \\
\text { mempunyai keahlian karena pelatihan yang dikutinya" } \\
\text { (wawancara } 12 \text { November 2013) } \\
\text { "Diklat belum dapat dikuti karena keterbatasan anggaran } \\
\text { serta ijin dari pimpinan dan rata-rata masa kerja pegawai di } \\
\text { atas } 10 \text { tahun" (wawancara } 12 \text { November 2013) }\end{array}$ \\
\hline $\begin{array}{l}\text { 3. Sediaan } \\
\text { Anggaran }\end{array}$ & $\begin{array}{c}\text { Kepala Sub Bagian Tata } \\
\text { Usaha }\end{array}$ & $\begin{array}{l}\text { "Untuk penyusunan anggaran masih terkendala jaringan } \\
\text { internet dan SDM, sedangkan realisasinya terkendala hal-hal } \\
\text { teknis begitupun dengan jumlah belum ideal" } \\
\text { (wawancara } 12 \text { November } 2013 \text { ) }\end{array}$ \\
\hline $\begin{array}{l}\text { 3. } \\
\text { Sediaan } \\
\text { Sarana }\end{array}$ & $\begin{array}{c}\text { Kepala Sub Bagian Tata } \\
\text { Usaha }\end{array}$ & $\begin{array}{l}\text { "Fasilitas Kantor sudah ada namun belum memadai, karena } \\
\text { masih memakai peralatan yang lama dan rentan mengalami } \\
\text { kerusakan" (wawancara } 12 \text { November 2013) }\end{array}$ \\
\hline $\begin{array}{l}\text { 4. Sediaan } \\
\text { Prasarana }\end{array}$ & $\begin{array}{l}\text { Kepala Sub Bagian Tata } \\
\text { Usaha } \\
\text { Staf }\end{array}$ & $\begin{array}{l}\text { "Sudah ada gedung dan tanah seluas } 2000 \mathrm{M}^{2} \text { serta ruangan } \\
\text { untuk tiap-tiap bagian" (wawancara } 12 \text { November 2013) } \\
\text { "Ada beberapa ruangan yang ukurannya kurang sesuai dalam } \\
\text { memperlancar aktivitas pegawai" (wawancara } 12 \text { November } \\
2013 \text { ) } \\
\text { "Ruangan kantor kurang besar sehingga terkesan } \\
\text { berhimpitan, belum lagi jalan masuk masih tanah kasar dan } \\
\text { tidak adanya pagar" (wawancara } 13 \text { November 2013) } \\
\text { "Ruang tunggu hanya ada } 1 \text { kursi panjang sehingga kalau } \\
\text { banyak orang..yah terpaksa berdiri saja" (wawancara } 13 \\
\text { November 2013) }\end{array}$ \\
\hline $\begin{array}{l}\text { 5. Efisiensi } \\
\text { Birokrasi }\end{array}$ & Kepala Kantor & $\begin{array}{l}\text { "Pegawai Kantor Pertanahan idealnya } 50 \text { orang ke atas bukan } \\
\text { hanya } 30 \text { orang sehingga target sertifikasi pertanahan dapat } \\
\text { tercapai" (wawancara } 12 \text { November } 2013 \text { ) }\end{array}$ \\
\hline
\end{tabular}




\section{Disiplin Kerja}
Kepala Sub Bagian Tata Usaha

Kepala Seksi Sengketa, Konflik dan Perkara

Staf

Masyarakat
"Kedisiplinan apel pagi belum mencapai 75\% karena disebabkan jauhnya jarak kantor dengan rumah dan urusan keluarga" (wawancara 12 November 2013) "Jika pegawai terlambat ke kantor pasti berakibat pada penyelesaian berkas dan waktu gelar perkara sedangkan untuk jangka waktu penyelesaian berkas tergantung tingkat kerumitannya" (wawancara 13 November 2013) "Kita selalu menghormati atasan dan teman sekerja dan selalu berkoordinasi ke atasan jika mendapati masalah dalam pekerjaan" (wawancara 13 November 2013) "Kalau yang saya lihat sih, mereka kadang masih suka mengobrol padahal ini masih jam kerja" (wawancara 13 November 2013)

Sumber: Data Primer 2014

Aspek yang berkontribusi dalam peningkatan kualitas kinerja (output) organisasi pemerintahan menurut Mahmudi (2010) dan Pasalong (2010) adalah masukan (input) dan aktivitas (process). Dalam penelitian ini variabel dependen yaitu kualitas kinerja (output) Kantor Pertanahan Kabupaten Rote Ndao dipengaruhi oleh variabel independen yaitu ketersediaan sumber daya manusia, ketersediaan anggaran, ketersediaan sarana, ketersediaan prasarana, efisiensi birokrasi dan disiplin kerja. Berdasarkan hasil korelasi terdapat hubungan yang kuat dan signifikan dari kedelapan variabel independent tersebut dengan variabel dependent kualitas kinerja (output) Kantor Pertanahan Kabupaten Rote Ndao. Selain itu, variabel-variabel independen tersebut secara simultan dan parsial berpengaruh terhadap kualitas kinerja (output) Kantor Pertanahan Kabupaten Rote Ndao.

\section{Implikasi Teoritis}

Hasil penelitian ini menguatkan pendapat teori masukan (input) menurut LAN-RI (1999), yaitu segala sesuatu yang dibutuhkan agar pelaksanaan kegiatan dapat berjalan untuk menghasilkan keluaran atau hasil langsung dari proses (output) dalam organisasi. Indikator kinerja yang dimaksud oleh LAN RI (1999), adalah ukuran kuantitatif dan kualitatif yang menggambarkan tingkat pencapaian suatu sasaran atau tujuan yang telah ditetapkan dengan mempertimbangkan indikator masukan (input). LAN RI mendefinisikan indikator masukan (input), adalah segala sesuatu yang dibutuhkan agar pelaksanaan kegiatan/aktivitas (process) dapat berjalan untuk menghasilkan keluaran/hasil langsung dari proses (output). Indikator masukan (input), dapat berupa: ketersediaan sumber daya manusia, anggaran, sarana, dan prasarana.

Teori masukan (input), teori lainnya yaitu aktivitas (process) yang dikemukakan oleh Mahmudi (2010:98), yaitu kegiatan pelayanan yang dilakukan aparatur pemerintah dalam suatu organisasi untuk mencapai tujuan. Terdapat beberapa determinan yang membentuk aktivitas (process), yaitu efisiensi birokrasi dan disiplin kerja. Efisiensi merupakan perbandingan antara input dengan output dalam birokrasi sebagai tempat pengelolaan pelayanan kepada publik dalam wujud administratif. Dilihat dari perbandingan antara rasio pegawai dengan volume kerja yang diselesaikan pegawai setiap hari kerja, sehingga hal ini merupakan aspek yang berkontribusi dalam mempengaruhi kinerja, sedangkan disiplin kerja merupakan aspek pembentuk aktivitas (process) yang berhubungan dengan disiplin kerja yang baik dari seorang pegawai akan melahirkan perilaku positif yang berdampak pada kinerja yang dihasilkan.

Teori keluaran (output) menurut Mahmudi (2010:99), yaitu sesuatu yang dicapai dari suatu kegiatan berupa fisik dan non fisik. Teori output menurut Widodo (2008) adalah keluaran atau hasil langsung dari suatu proses. Teori kualitas kinerja (output) organisasi pemerintahan menurut Mahmudi (2010) dan Pasalong (2010), yaitu hasil langsung dari suatu proses atau kegiatan berupa bukti fisik dan non 
fisik untuk memenuhi kebutuhan masyarakat. Konklusinya bahwa dengan menggunakan determinan input dan determinan process akan meningkatkan output (kualitas kinerja organisasi pemerintahan) demi kepentingan masyarakat.

\section{Implikasi Praktis}

Penelitian ini diharapkan dapat bermanfaat bagi Kantor Pertanahan Kabupaten Rote Ndao dengan memperhatikan faktor-faktor masukan (input) dan aktivitas (process) ketika melaksanakan tugas dan pekerjaan dalam rangka peningkatan kualitas kinerja (output) Kantor Pertanahan Kabupaten Rote Ndao: 1) Memberikan hasil pekerjaan yang baik dilihat dari segi kuantitas dan kualitas dengan adanya dukungan faktor masukan (input) dan aktivitas (process) dalam melaksanakan segala tugas dan pekerjaan yang diberikan sesuai arahan dan bimbingan dari atasan yang diselesaikan dengan tepat waktu atau jadwal yang ditentukan; 2) mempererat kerjasama di antara sesama pegawai maupun dengan mitra lainnya yang termasuk dalam bagian sistem pekerjaan pada Kantor Pertanahan Kabupaten Rote Ndao sehingga dapat memberikan kekuatan kepada organisasi dalam memudahkan ketika menyelesaikan sebuah pekerjaan; 3) semakin memperkuat nilai-nilai dasar organisasi yaitu optimalisasi pelayanan prima dan profesional Kantor Pertanahan Kabupaten Rote Ndao.

\section{Simpulan}

Pelayanan publik pada dasarnya menyangkut aspek kehidupan yang sangat luas. Pada kehidupan bernegara, maka pemerintah memiliki fungsi memberikan pelayanan publik yang diperlukan masyarakat. Pelayanan publik dapat dirubah dan ditingkatkan menjadi "prima", birokrasi beradaptasi dengan perubahan dan memahami kebutuhan masyarakat yang dilayani. Capacity building yang tidak konsisten dan tidak taat azas dari institusi pelayanan publik telah menjadi faktor dominan bagi melemahnya kinerja birokrasi, selain itu faktor-faktor internal birokrasi, seperti: sumber daya dan struktur organisasi secara bersama-sama menjadi hambatan bagi upaya peningkatan kualitas kinerja. Pada era globalisasi, aparatur negara harus siap dan mampu menghadapi perubahan yang sangat dinamis dan tantangan persaingan dalam berbagai bidang. Oleh karena itu, penyelenggaraan pelayanan publik di tubuh birokrasi harus terus dijalankan demi terciptanya pelayanan prima bagi masyarakat.

\section{Daftar Pustaka}

Duit R, Treagust D and Widodo A (2008) Teaching science for conceptual change: Theory and Practice. In Vosniadou S (ed.), International Handbook of Research on Conceptual Change, New York, USA: Routledge, pp. 629-646.

LAN RI (1999) Prinsip-Prinsip Penyelenggaraan Negara. Jakarta.

Mahmudi (2010) Manajemen kinerja sektor publik. Yogyakarta: Akademi Manajemen Perusahaan. YKPN.

Pasalong H (2010) Kepemimpinan Birokrasi. Bandung: Alfabeta.

Undang-Undang Nomor 5 (1960) tentang Peraturan Dasar Pokok-Pokok Agraria.

Undang-Undang Nomor 32 (2004) tentang Pemerintahan Daerah. 